STUDIA EDUKACYJNE NR 31/2014

ERNIS AJDAROW

Państwowa Stużba Więzienna

w Kirgistanie

\title{
SYSTEM PENITENCJARNY W KIRGISTANIE: STRUKTURA I ZAKŁADY KARNE
}

\begin{abstract}
Ajdarow Ernis, System penitencjarny w Kirgistanie: struktura i zakłady karne [Penitentiary System of Kyrgyzstan: Structure and Function of Prisons]. Studia Edukacyjne nr 31, 2014, Poznań 2014, pp. 339-362. Adam Mickiewicz University Press. ISBN 978-83-232-2781-6. ISSN 1233-6688

Penitentiary system of Kyrgyzstan is a small part of the heritage, totalitarian penitentiary system of the USSR. From the moment of Kyrgyzstan's independence, the penitentiary system of Kyrgyzstan faces some difficulties but now it's in the phase of development. The paper presents an overview of the current state of the prison system, such as management structure, prison staff, criminal subculture, prison conditions in the period of transformation.
\end{abstract}

Key words: penitentiary system of Kyrgyzstan, prison, transformation, criminal subculture

System penitencjarny w Kirgistanie to tylko niewielka część spuścizny po totalitarnym systemie penitencjarnym w ZSSR. Od momentu uzyskania niepodległości przez Kirgistan, jego system penitencjarny napotkał szereg problemów, ale obecnie jest na etapie rozwoju. Niniejsza praca prezentuje obecny stan systemu więziennictwa, między innymi strukturę zarządzania, kadrę pracowniczą, subkulturę kryminalną, stan więzień $\mathrm{w}$ okresie ich transformacji.

Omawiając system penitencjarny w Kirgistanie, należy skorzystać ze sposobności poznania tego kraju, bo, niestety, wielu ludzi na świecie Kirgistanu nie zna, a dobrze byłoby to zmienić.

Pod względem geograficznym obszar ten znajduje się w centrum kontynentu euroazjatyckiego, na rozległych połaciach górskich pasm Tien-szanu i Pamiro-Ałtaju. Na jego terytorium występują wszystkie typy krajobrazów: od nieprzyjaznych i niedostępnych szczytów górskich, przez alpejskie łąki, od których aromatu, mieszającego się z kryształowo czystym górskim po- 
wietrzem, kręci się w głowie, po wartkie górskie rzeki i jeziora, to prawdziwe perły w oprawie ośnieżonych szczytów ${ }^{1}$ - tak wygląda przyroda Kirgistanu.

Granicząc od północy z Kazachstanem, od zachodu - z Uzbekistanem, od południowego zachodu - z Tadżykistanem, a od wschodu - z Chinami, jest to kraj wieloetniczny, który zamieszkuje około 100 narodowości². Stolicą Kirgistanu jest Biszkek, liczący prawie milion mieszkańców, natomiast cały kraj w 2013 roku zamieszkiwało 563100 ludzi³.

Zgodnie z Konstytucją, Kirgistan jest państwem suwerennym, demokratycznym, opartym na poszanowaniu prawa, świeckim, unitarnym i socjalnym. Parlament Republiki Kirgiskiej to najwyższy organ przedstawicielski, sprawujący władzę ustawodawczą, pełniący funkcje kontrolne $w$ ramach swoich uprawnień ${ }^{4}$. Jest to jedyna republika parlamentarna na poradzieckim obszarze w Azji Środkowej. Należy podkreślić, że w Kirgistanie pokojowo współistnieją różne wyznania (muzułmanie - 83\%, chrześcijanie - 15\%5 , inne religie $-2 \%$ ).

Rozpatrując współczesną historię tego kraju, od 1924 do 1991 roku stanowił on część Związku Radzieckiego, co odbiło się na jego rozwoju. $\mathrm{W}$ okresie tym nastąpiły radykalne zmiany $\mathrm{w}$ dziedzinie edukacji, kultury i przemysłu, co również negatywnie odzwierciedliło się przede wszystkim w represyjnej i totalitarnej polityce państwa.

Historycznym dowodem na to może być system penitencjarny w Kirgistanie, stanowiący niewielką część spuścizny po olbrzymim systemie pracy przymusowej ZSRR, kiedy za pomocą zakładów karnych osiągano cele nie tylko izolacji niepożądanych dla reżimu „wrogów ludu”, myślących inaczej, niepopierających ideologię partii komunistycznej, ale także bezpłatnego wykorzystywania ich do pracy na wielkich budowach socjalizmu6.

\footnotetext{
${ }^{1}$ Wyszukiwarka „For.kg”, URL: http://www.for.kg/kyrgyzstan-ru.html [dostęp: 09.02.2014].

${ }^{2}$ Oficjalna strona internetowa Prezydenta Republiki Kirgiskiej, URL: http://www. president.kg/ru/kyrgyzstan [dostęp: 10.02.2014].

${ }^{3}$ Oficjalna strona internetowa Krajowego Komitetu Statystycznego Republiki Kirgiskiej (KKS), URL: http://stat.kg/images/stories.docs/Yearbook/Demo/3.\%20chislennost\&20i\%20 plot.pdf [dostęp: 10.02.2014].

${ }^{4}$ Konstytucja Republiki Kirgiskiej wprowadzona w życie ustawą Republiki Kirgiskiej z 27 czerwca 2010 roku, art. 1, art. 70.

${ }^{5}$ Religia w Kirgistanie, URL: http://www.advantour.com/rus/kyrgyzstan/religion.html [dostęp: 16.02.2014].

6 Raport roczny o prawach człowieka w Republice Kirgiskiej w roku 2006, opublikowany w ramach działalności Rady Praw Człowieka przy wsparciu Duńskiego Instytutu Praw Człowieka w programie współpracy w Azji Środkowej Ministerstwa Spraw Zagranicznych Królestwa Danii, Biszkek 2007, s. 112.
} 
Zakłady karne Republiki Kirgiskiej pamiętają czasy, kiedy stanowiły nieodłączną część radzieckiego systemu penitencjarnego, ogromnego zarówno pod względem liczby więźniów, jak też liczby nadzorujących ich pracowników oraz infrastruktury: bazy produkcyjnej, wielkości produkcji itp. Nieprzypadkowo GUIN7 (GUŁAG ${ }^{8}$ ) zwany był „państwem w państwie". Jednakże, wraz z upadkiem ZSRR upadł także system penitencjarny - potężna baza przemysłowa została zniszczona i rozkradziona, a finansowe wsparcie realizowało tylko $20-30 \%$ zapotrzebowania, co starczało zaledwie na wynagrodzenie dla pracowników i wyżywienie więźniów, podczas gdy ich liczba zaczęła rosnąć $\mathrm{w}$ tempie arytmetycznym ${ }^{9}$.

Należy zatem podkreślić, że od momentu uzyskania przez Kirgistan niepodległości, system penitencjarny zmaga się z ogromem trudności i do dzisiaj pokonuje trudną drogę transformacji, znajdując się $w$ fazie reform.

Ograniczone zasoby finansowe nie pozwalają Republice Kirgiskiej na pełną realizację wszystkich kierunków reform systemu penitencjarnego, $\mathrm{z}$ wyjątkiem tych, które nie wymagają dużych nakładów finansowych. Znaczny wkład $\mathrm{w}$ reformę systemu wnoszą także instytucje międzynarodowe i organizacje pozarządowe.

Należy zaznaczyć, że współczesny system penitencjarny w Kirgistanie odznacza się osobliwą specyfiką, która polega na próbie połączenia pozostałości radzieckiego systemu więziennictwa $\mathrm{z}$ nowoczesnym podejściem do odbywania kary, wyznaczanym przez odpowiednie normy międzynarodowe. Ze względu na otwartość tego systemu10 i jego dążenie do innowacji, wyjątkowość ta przyciąga uwagę społeczności międzynarodowej oraz odpowiednich środowisk naukowych, o czym świadczy duża liczba realizowanych obecnie projektów.

${ }^{7}$ GUIN - Gławnoje uprawlenije ispołnienija nakazanij (Główny Zarząd Służby Więziennej) - organ zarządzający zakładami karnymi w czasach niepodległości Kirgistanu do 2009 roku.

8 GUŁAG - Gławnoje uprawlenije isprawitielno-trudowych łagieriej i kolonij (Główny Zarząd Poprawczych Obozów Pracy) - oddział NKWD ZSSR, MSW ZSSR, Ministerstwa Sprawiedliwości ZSSR zarządzający miejscami przymusowego pobytu i osadzenia w latach 1934-1960, URL: http://ru.wikipedia.org/wiki/\%D0\%93\%D0\%A3\%D0\%9B\%D0\%B0\%D0\%B3 [dostęp: 12.02.2014].

9 M. Dżamankułow i in., Prawa czełowieka w processie rieformirowanija pienitiencyarnoj sistiemy w Kyrgyzskoj Riespublikie, Biszkek 2007, s. 4-5.

10 W systemie penitencjarnym w Kirgistanie w 2013 roku realizowano 19 niepaństwowych projektów, z finansowym wsparciem organizacji międzynarodowych i pozarządowych w zakresie leczenia, resocjalizacji osób zwolnionych z zakładów karnych, poprawy warunków przetrzymywania więźniów itp. W roku 2013 wydano łącznie 260 pozwoleń 51 organizacjom, w ten sposób zakłady PSW odwiedziło 1000 osób. Patrz: Wyniki działalności operacyjno-stużbowej i finansowo-gospodarczej Państwowej Stużby Więziennej przy Rządzie Republiki Kirgiskiej w roku 2013, s. 1. 
Po uzyskaniu przez Kirgistan niepodległości w 1991 roku, system penitencjarny podlegał Ministerstwu Spraw Wewnętrznych, co nie odpowiadało światowym standardom. W związku z powyższym oraz $\mathrm{z}$ uwagi na brak rozwoju systemu penitencjarnego w reżimie policyjnym, w 2002 roku został on przekazany Ministerstwu Sprawiedliwości, w składzie którego działał do listopada 2009 roku11. Decyzja ta była rzeczywiście radykalna i świadczyła o zamiarze postępowania zgodnie $\mathrm{z}$ powszechnie przyjętymi zasadami humanizmu i demokracji - to właśnie wówczas rozpoczął się proces reformowania systemu ${ }^{12}$.

W grudniu 2009 roku utworzono Państwową Służbę Więzienną (Gosudarstwiennaja służba inspołnienija nakazanij - GSIN), podporządkowaną rządowi Republiki Kirgiskiej (dalej PSW), która jest organem władzy wykonawczej, odpowiedzialnym za przestrzeganie prawa i realizującym politykę państwową $\mathrm{w}$ zakresie funkcjonowania systemu karnego. Zgodnie $\mathrm{z}$ Regulaminem, dyrektor PSW jest wybierany na to stanowisko przez premiera Republiki Kirgiskiej13, co zakłada bezpośrednie podporządkowanie PSW rządowi. Ma on trzech zastępców, w tym jednego głównego, którzy są powoływani i odwoływani $\mathrm{z}$ tej posady także przez premiera, na wniosek dyrektora, podlegają bezpośrednio dyrektorowi i zarządzają działalnością PSW $\mathrm{w}$ ramach swoich uprawnień ${ }^{14}$ (działalność operacyjna, finansowogospodarcza, ochronno-konwojowa).

W skład PSW wchodzą urzędy i organy wykonujące wyroki. Obejmuje on także zespół państwowych instytucji prawnych, społeczno-ekonomicznych i psychologiczno-pedagogicznych ${ }^{15}$. Składa się z 31 instytucji, w tym z:

- 11 zakładów karnych, w których więźniowie odbywają kary w strzeżonych kompleksach typu zamkniętego, przebywając $\mathrm{w}$ pomieszczeniach typu koszarowego. Zgodnie z formalną klasyfikacją zakładów karnych, są to trzy kolonie karne o zaostrzonym rygorze, przewidziane przez prawo dla mężczyzn, którzy popełnili przestępstwa w warunkach recydywy, jeśli

11 Prawa osób starszych w miejscach pozbawienia wolności w Republice Kirgiskiej - raport z pierwszego monitoringu sporządzony w ramach projektu: „Monitoring warunków przetrzymywania i przestrzegania praw osób starszych $\mathrm{w}$ miejscach pozbawienia wolności i organizacji pracy społecznej ze skazanymi osobami starszymi", przy wsparciu Delegacji Unii Europejskiej w Republice Kirgiskiej, Biszkek 2011, s. 6.

12 M. Dżamankułow i in., Prawa czełowieka, s. 14.

${ }^{13}$ Regulamin Państwowej Służby Więziennej przy Rządzie Republiki Kirgiskiej zatwierdzony Postanowieniem Rządu Republiki Kirgiskiej nr 775 z 18 grudnia 2009 roku (Regulamin PSW), pkt 1, 13, URL: http:/ /gsin.kg/index.php?id=13 [dostęp: 12.02.2014].

14 Tamże. s. 112.

15 Raport roczny o prawach człowieka w Republice Kirgiskiej w roku 2006, Biszkek 2007, 
wcześniej odbywali kary pozbawienia wolności, oraz przestępstwa ciężkie $\mathrm{w}$ warunkach recydywy; cztery kolonie karne o wzmocnionym rygorze dla mężczyzn skazanych po raz pierwszy za popełnienie ciężkich lub szczególnie ciężkich przestępstw; jedna kolonia poprawcza dla nieletnich płci męskiej; jeden zakład karny dla kobiet i dwa lecznicze zakłady karne dla osób chorych na gruźlicę. W systemie brakuje takich, przewidzianych przez prawo, instytucji, jak zakłady karne o zwykłym i nadzwyczajnym rygorze dla mężczyzn, a rygor więzienny stosowany jest tylko w jednym zakładzie;

- 14 kolonii typu otwartego, z zamieszkiwaniem zazwyczaj w specjalnie wyznaczonych budynkach, gdzie pod nadzorem odbywają kary osoby pozbawione wolności na okres nie dłuższy niż pięć lat za przestępstwa popełnione nieumyślnie, a także skazani przeniesieni z kolonii karnych po odbyciu odpowiedniej części kary;

- 6 aresztów śledczych przeznaczonych do przetrzymywania w celach osób, względem których zastosowano tymczasowe aresztowanie jako środek zapobiegawczy, czyli osób, przeciwko którym toczy się postępowanie przygotowawcze lub sądowe ( $w$ tym postępowanie odwoławcze $)^{16}$.

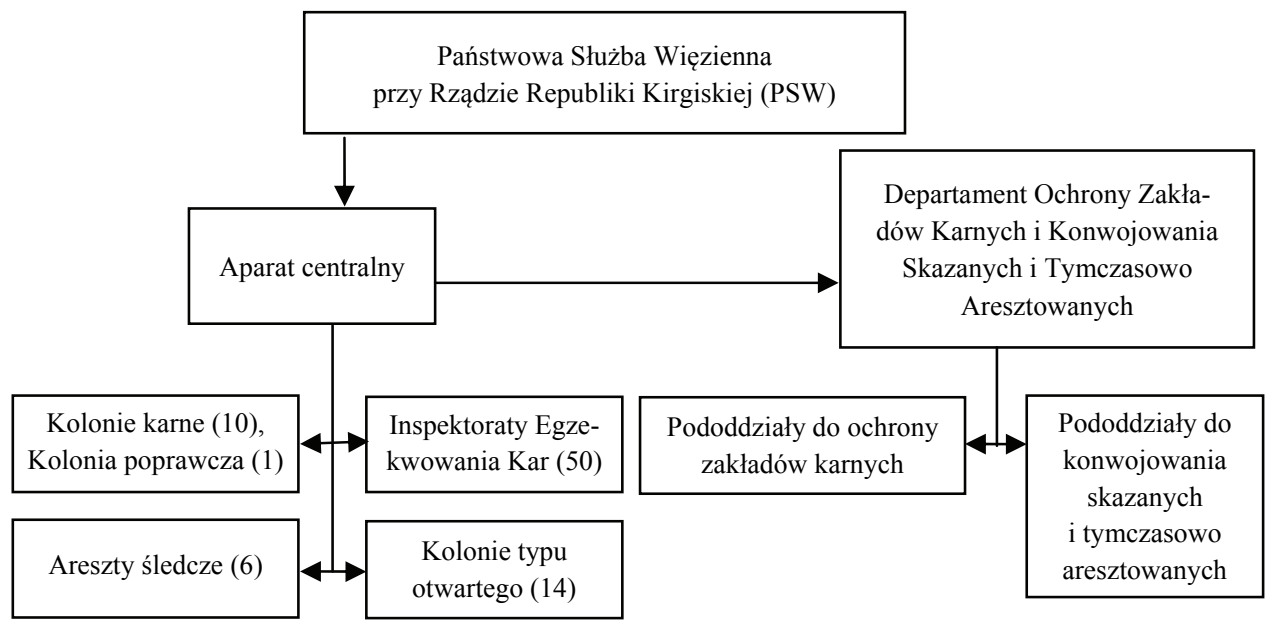

Ryc. 1

Źródło: S. Basztowienko, E. Ajdarow, Rukowodstwo po socyalnoj rabotie s pożyłymi licami, otbywajuszczimi nakazanije w uczrieżdienijach pienitiencyarnoj sistiemy Kyrgyzskoj Riespubliki, Biszkek 2012, s. 8.

Ponadto, do systemu należy Inspektorat Egzekwowania Kar, zajmujący się egzekwowaniem kar niezwiązanych z izolowaniem skazanego od społe-

16 Oficjalna strona internetowa Państwowej Służby Więziennej przy Rządzie Republiki Kirgiskiej (PSW), URL: http://www.gsin.kg/index.php?id=15 [dostęp: 13.02.2014]. 
czeństwa i wykonywaniem innych czynności o charakterze karnoprawnym ${ }^{17}$ oraz Departament Ochrony Zakładów Karnych i Konwojowania Skazanych i Tymczasowo Aresztowanych, zajmujący się ochroną i obroną zakładów karnych oraz konwojowaniem skazanych i tymczasowo aresztowanych $^{18}$ - patrz rycina 1 .

Lokalizację zakładów PSW przedstawiono w tabeli 1, w której wymieniono rodzaje i liczbę zakładów w każdym obwodzie. Większość zakładów typu zamkniętego znajduje się w północnej części kraju - 65\% (obwód czujski), co z kolei jest związane z szybkim rozwojem przemysłu w tym regionie w czasach radzieckich.

Tabela 1

Lokalizacja zakładów PSW według obwodów w Kirgistanie

\begin{tabular}{|c|c|c|c|c|c|c|}
\hline Obwody & \begin{tabular}{|c|} 
Kolonie \\
karne (za- \\
kłady typu \\
zamkniętego \\
dla męż- \\
czyzn) \\
\end{tabular} & $\begin{array}{l}\text { Aresz- } \\
\text { ty } \\
\text { śledcze }\end{array}$ & $\begin{array}{c}\text { Kolonia } \\
\text { karna } \\
\text { dla } \\
\text { kobiet }\end{array}$ & $\begin{array}{c}\text { Kolonia } \\
\text { poprawcza } \\
\text { (dla nieletnich) }\end{array}$ & $\begin{array}{c}\text { Kolonie } \\
\text { typu } \\
\text { otwartego }\end{array}$ & $\begin{array}{c}\text { Inspektoraty } \\
\text { Egzekwowa- } \\
\text { nia Kar }\end{array}$ \\
\hline Czujski & 8 & 3 & 1 & 1 & 7 & 12 \\
\hline Tałaski & & & & & 2 & 3 \\
\hline Issykkulski & & 1 & & & 2 & 7 \\
\hline Naryński & & 1 & & & 1 & 5 \\
\hline $\begin{array}{l}\text { Dżalala- } \\
\text { badzki }\end{array}$ & 1 & & & & & 11 \\
\hline Oszyński & & 1 & & & 1 & 8 \\
\hline Batkeński & & & & & 1 & 4 \\
\hline Razem & 9 & 6 & 1 & 1 & 14 & 50 \\
\hline
\end{tabular}

Źródło: opracowanie własne na podstawie danych z oficjalnej strony internetowej PSW, URL: http://gsin.kg/index.php?id=57 [dostęp: 18.02.2014].

Obecnie, wraz z pojawieniem się realnej szansy na zmianę podejścia do walki z przestępczością nie z pozycji karnej, a z pozycji zadośćuczynienia dla ofiar przestępstw, pojawiła się konkretna możliwość kształtowania humanitarnej polityki karnej państwa za pomocą mechanizmów prawnych ${ }^{19}$.

Według stanu z 31.12.2006 roku, w zakładach systemu penitencjarnego przetrzymywano 15100 obywateli, tak więc zagęszczenie „więziennej” po-

17 Oficjalna strona internetowa PSW, URL: http://gsin.kg/index.php?id=57 [dostęp: 13.02.2014].

18 Tamże.

${ }^{19}$ A. Szagiwalijew i in., Gumanizacyja ugołownogo zakonodatielstwa Kyrgyzskoj Riespubliki: problemy tieorii i praktiki, Biszkek 2009, s. 154. 
pulacji wynosiło 285 osób na 100000 mieszkańców, a Kirgistan zajmował 36. miejsce na świecie pod względem liczby osadzonych ${ }^{20}$. W wyniku stosowania, na szeroką skalę, Ustawy Republiki Kirgiskiej z 25 czerwca 2007 roku ${ }^{21}$, mającej na celu humanizację polityki karnej państwa, wielkość populacji więziennej w Kirgistanie, według stanu na dzień 1 stycznia 2012 roku, spadła do 9828 osadzonych - 181 osób na 100000 mieszkańców kraju, a Kirgistan znalazł się tym samym na 77. miejscu na świecie ${ }^{22}$. To ponad trzy razy mniej niż w USA (707) ${ }^{23}$, 2,5 razy mniej niż w Rosji (472) ${ }^{24}$ i nieco mniej niż w Polsce $(205)^{25}$, jednak wskaźnik ten jest trzy razy wyższy niż w Szwecji $(67)^{26}$ oraz dwa razy wyższy aniżeli we Francji (100)27.

Stosowanie powyższej ustawy, oprócz zmniejszenia liczby skazanych, przyczyniło się do zmniejszenia limitu zapełniania zakładów systemu penitencjarnego, który w 2006 roku wynosił $20263^{28}$ miejsc dla osadzonych, a w roku 2012 - już tylko 17 72429, czyli limit został zmniejszony o 2539 miejsc. Odbyło się to kosztem likwidacji kolonii typu otwartego, których liczba od 2006 roku spadła z 19 do 14 (stan na dzień dzisiejszy - patrz ryc. 1), tym samym zlikwidowano 5 kolonii typu otwartego ${ }^{30}$.

Na szczególną uwagę zasługuje zagadnienie przestępczości kobiet, stanowiące osobny rodzaj przestępczości z uwagi na jej cechy szczególne i spe-

\footnotetext{
${ }^{20}$ Raport roczny o prawach człowieka w Republice Kirgiskiej, s. 112-113.

${ }^{21}$ Ustawa Republiki Kirgiskiej o wprowadzeniu zmian i uzupełnień do Kodeksu karnego Republiki Kirgiskiej, Kodeksu postępowania karnego Republiki Kirgiskiej, Kodeksu postępowania administracyjnego Republiki Kirgiskiej, Kodeksu karnego wykonawczego Republiki Kirgiskiej, do ustaw Republiki Kirgiskiej o Sądzie Najwyższym Republiki Kirgiskiej i sądach lokalnych, o prokuraturze Republiki Kirgiskiej, o trybie i warunkach przetrzymywania w areszcie osób zatrzymanych $\mathrm{w}$ związku z podejrzeniem popełnienia przestępstwa i oskarżonych o popełnienie przestępstwa, o ogólnych zasadach amnestii i ułaskawienia, o wprowadzeniu w życie Kodeksu karnego wykonawczego Republiki Kirgiskiej oraz o wprowadzeniu w życie Kodeksu karnego Republiki Kirgiskiej (ustawa o humanizacji) opublikowana w gazecie „Erkin-TOO” 3 lipca 2007 r., nr 47-48.

22 International Centre for Prison Studies (ICPS), URL: http://www.prisonstudies.org/ country/kyrgyzstan [dostęp: 14.02.2014].

${ }^{23}$ ICPS, URL: http://www.prisonstudies.org/country/united-states-america [dostęp: 14.02.2014].

${ }^{24}$ ICPS, URL: http://www.prisonstudies.org/country/russian-federation [dostęp: 14.02.2014].

25 ICPS, URL: http:/ /www.prisonstudies.org/country/poland [dostęp: 14.02.2014].

${ }^{26}$ ICPS, URL: http://www.prisonstudies.org/country/sweden [dostęp: 14.02.2014].

${ }^{27}$ ICPS, URL: http://www.prisonstudies.org/country/france [dostęp: 14.02.2014].

28 Oficjalny dokument OBWE "Ocena stanu systemu penitencjarnego w Republice Kirgiskiej", Biszkek 2006, s. 15.

${ }^{29}$ Raport Wydziału Wykonywania Orzeczeń Sądowych i Ewidencji PSW z 1.07.2012 r., s. 6.

30 Oficjalny dokument OBWE, s. 14.
} 
cyficzną strukturę, która nie pokrywa się z przestępczością mężczyzn, różniąc się od niej nie tylko ilościowo, ale także jakościowo ${ }^{31}$.

Z oficjalnych statystyk wynika, że skazanych kobiet jest mniej niż mężczyzn, co stanowi 8-11\% całkowitej liczby skazanych, jednak w 1991 roku wskaźnik ten wynosił 7,8\%, a w roku 2012 - już 10,9\%, co świadczy o wyraźnym wzroście przestępczości kobiet w Kirgistanie.

Tabela 2

Liczba skazanych według płci i zawodu wykonywanego w momencie popełnienia przestępstwa

\begin{tabular}{|l|r|r|r|r|r|r|r|r|r|r|r|}
\hline \multicolumn{1}{|c|}{ Rok } & $\mathbf{1 9 9 1}$ & $\mathbf{1 9 9 2}$ & $\mathbf{1 9 9 3}$ & $\mathbf{1 9 9 4}$ & $\mathbf{1 9 9 5}$ & $\mathbf{1 9 9 6} \mathbf{1 9 9 7}$ & $\mathbf{1 9 9 8}$ & $\mathbf{1 9 9 9}$ & $\mathbf{2 0 0 0}$ & $\mathbf{2 0 0 1}$ \\
\hline $\begin{array}{l}\text { Razem } \\
\text { skazanych }\end{array}$ & 8894 & 10947 & 15011 & 14323 & 17599 & 17515 & 19597 & 18484 & 17652 & 20168 & 17681 \\
\hline Kobiety & 694 & 838 & 1022 & 1055 & 1317 & 1199 & 1740 & 1896 & 1828 & 2084 & 1905 \\
\hline Mężczyźni & 8200 & 10109 & 13989 & 13268 & 16282 & 16316 & 17857 & 16588 & 15824 & 18084 & 15776 \\
\hline $\begin{array}{l}\text { Osoby skazane } \\
\text { ponownie }\end{array}$ & 1259 & 1409 & 2024 & 2021 & 1497 & 558 & ----- & 4052 & 3934 & 4282 & 3583 \\
\hline $\begin{array}{l}\text { Osoby zdolne do } \\
\text { pracy, które nie } \\
\text { pracowały i nie } \\
\text { studiowały }\end{array}$ & 2000 & 3133 & 5525 & 6731 & 10217 & 14673 & 16391 & 11861 & 12680 & 14562 & 13859 \\
\hline \multicolumn{1}{|c|}{ Rok } & $\mathbf{2 0 0 2}$ & $\mathbf{2 0 0 3}$ & $\mathbf{2 0 0 4}$ & $\mathbf{2 0 0 5}$ & $\mathbf{2 0 0 6}$ & $\mathbf{2 0 0 7}$ & $\mathbf{2 0 0 8}$ & $\mathbf{2 0 0 9}$ & $\mathbf{2 0 1 0}$ & $\mathbf{2 0 1 1}$ & $\mathbf{2 0 1 2}$ \\
\hline $\begin{array}{l}\text { Razem } \\
\text { skazanych }\end{array}$ & 17091 & 16444 & 14748 & 13385 & 13480 & 12663 & 10666 & 9797 & 8524 & 9199 & 8206 \\
\hline \begin{tabular}{l} 
Kobiety \\
\hline Mężczyźni
\end{tabular} 1938 & 1884 & 1783 & 1531 & 1540 & 1501 & 1099 & 1119 & 1004 & 969 & 895 \\
\hline $\begin{array}{l}\text { Osoby skazane } \\
\text { ponownie }\end{array}$ & 3134 & 2853 & 2632 & 2635 & 2665 & 2386 & 2239 & 2002 & 1561 & 2557 & 1298 \\
\hline $\begin{array}{l}\text { Osoby zdolne do } \\
\text { pracy, które nie } \\
\text { pracowały i nie } \\
\text { studiowały }\end{array}$ & 12862 & 12321 & 10771 & 9961 & 10051 & 9586 & 7922 & 7390 & 6559 & 7269 & 6379 \\
\hline
\end{tabular}

Źródło: oficjalna strona internetowa Krajowego Komitetu Statystycznego: URL: http://www.stat.kg/stat.files/din.files/prest/5060007.pdf

A. Quetelet niższą przestępczość kobiet tłumaczył nie tylko ich fizyczną słabością, ale także brakiem uczestnictwa w życiu społecznym, czy skupieniem na obowiązkach rodzinnych. Jednakże, wraz z włączaniem się coraz większej liczby kobiet w życie społeczne i działalność zawodową, ich prze-

31 A. Jakowlew, Indiwidualnaja profilaktika priestupnogo powiedienija, Gorki 1997, s. 116; Prawa czełowieka $w$ processie rieformirowanija pienitiencyarnoj sistiemy w Kyrgyzskiej Riepublikie, red. M. Dżamankułow i in., Biszkek 2007, s. 189. 
stępczość ${ }^{32}$ może rosnąć. Tłumaczenie to odzwierciedla dokładnie sytuację z przestępczością kobiet $\mathrm{w}$ Kirgistanie, ponieważ ostatnio kobiety zaczęły odgrywać ważną rolę w życiu społecznym, biznesie i polityce krajowej.

Należy także zwrócić uwagę na ryzyko recydywy, która powoduje, że ponownie popełniając przestępstwa, recydywiści mnożą wyrządzane społeczeństwu, państwu oraz poszczególnym osobom szkody, a także będąc źródłem praktyk przestępczych, obyczajów i specyficznej psychologii, aktywnie je rozprzestrzeniają, przyczyniając się do kryminalizacji ludności ${ }^{33}$. W Kirgistanie, jak wynika $\mathrm{z}$ danych przedstawionych w tabeli 2, liczba osób skazanych ponownie wynosi 30\%, co jest średnią statystyczną, w Norwegii recydywa plasuje się na poziomie $20 \% 34$, a jak podaje BBC Radio 4 (wg stanu z 2 września 2005 roku) poziom recydywy dla zwolnionych więźniów w Stanach Zjednoczonych wynosił 60\%, a w Wielkiej Brytanii - 50\% 35 .

Liczba osób niepracujących i niestudiujących $\mathrm{w}$ momencie popełnienia przestępstwa wynosi $75-80 \%$ całkowitej liczby skazanych i odsetek ten nie ulega zmianie.

Już w epoce oświecenia o upośledzeniu społecznym jako przyczynie przestępczości pisali tacy myśliciele, jak Locke, Helvetius, Holbach, Diderot, Wolter, Bentham ${ }^{36}$. Na uwagę zasługują szczególnie badania zdolności intelektualnych i poziomu wykształcenia przestępców prowadzone przez Cesare Lombroso, który w swojej pracy Sull'incremento del delitto in Italia zwracał uwagę, że gdyby można było określić średnią zdolność umysłową $\mathrm{z}$ taką samą dokładnością, jak średnią pojemność czaszki, to u przestępców byłaby ona niższa niż przeciętna. Za cechę wyróżniającą ich umysł uważa jego niską wydajność i związaną z tym niezdolność do wytrwałej i długiej pracy37. Na tej podstawie należy przyjąć, że człowieka na drogę przestępczą sprowadzają często takie aspekty społecznego upośledzenia, jak bezrobocie i brak wykształcenia.

32 J. Agiejewa, Żenskaja priestupnost': sowriemiennoje położenije i pricziny, Sledowatiel, 2001, 6, s. 39-40, URL: http://www.gadost.hut.ru/clog9.html [dostęp: 15.02.2014].

$33 \mathrm{~J}$. Bytko, Uczenije o riecydiwie priestuplenij w rossijskom ugolownom prawie: Istorija $i$ sowriemiennost', Diessiertacyja, URL: http://www.dissercat.com/content/uchenie-o-retsidiveprestuplenii-v-rossiiskom-ugolovnom-prave-istoriya-i-sovremennost [dostęp: 15.02.2014].

${ }_{34}$ Ostrow Bastoj: norwieżskaja tiurma dla osobo opasnych priestupnikow, URL: http://ttolk. $\mathrm{ru} / \mathrm{p}=4220$ [dostęp: 17.02.2014].

${ }_{35}$ Recidivism, URL: http://en.wikipedia.org/wiki/Recidivism [dostęp: 17.02.2014].

36 A.I. Dołgowa (red.), Kriminologija: Uczebnik dla wuzow, Moskwa 2001, s. 13-14, URL: http://ru.wikipedia.org/wiki/Licznost'_priestupnika\#cite_note-18 [dostęp: 17.02.2014].

37 D. Dril, Matoletnije priestupniki. Etiud po woprosu o czełowieczeskoj priestupnosti, jejo faktorach $i$ sriedstwach borby s niej, Moskwa 1884, URL: http://yurpsy.com/files/biblio/dril/05.htm [dostęp: 17.02.2014]. 
Największą grupę skazanych w Kirgistanie stanowią osoby w wieku 3949 lat, przy czym wskaźnik ten od początku niepodległości Kirgistanu wzrósł o około 10\%, ponieważ w roku 1991 wynosił 35\%, a w roku 2009 - już $46 \%$ ogólnej liczby skazanych. Mniej licznie reprezentowane są grupy wiekowe 14-17 lat i powyżej 50 lat, przy czym odnotowano dwukrotny spadek liczby nieletnich skazanych, których w roku 1991 było około 9,2\%, a w roku $2009-4,3 \%$, co z kolei tłumaczone jest humanizacją wymiaru sprawiedliwości dla nieletnich w Kirgistanie.

Tabela 3

Liczba skazanych według wieku w momencie popełnienia przestępstwa

\begin{tabular}{|c|c|c|c|c|c|c|c|c|c|c|c|}
\hline Wiek & 1991 & 1992 & 1993 & 1994 & 1995 & 1996 & 1997 & 1998 & 1999 & 2000 & 2001 \\
\hline Razem & 8894 & 10947 & 15011 & 14323 & 17599 & 17515 & 19597 & 18484 & 17652 & 20168 & 17681 \\
\hline $\begin{array}{l}14-17 \\
\text { lat }\end{array}$ & 827 & 983 & 1155 & 825 & 1208 & 1057 & 1166 & 1122 & 982 & 1314 & 1084 \\
\hline $\begin{array}{l}18-24 \\
\text { lat }\end{array}$ & 2390 & 3279 & 4733 & 4258 & 5201 & 4587 & 5033 & 4865 & 4356 & 4968 & 4672 \\
\hline $\begin{array}{l}25-29 \\
\text { lat }\end{array}$ & 2089 & 2490 & 3463 & 3196 & 3702 & 3742 & 4288 & 3666 & 3539 & 4043 & 3348 \\
\hline $\begin{array}{l}30-49 \\
\text { lat }\end{array}$ & 3105 & 3684 & 5120 & 5552 & 6833 & 7677 & 8865 & 7825 & 7950 & 8733 & 8044 \\
\hline $\begin{array}{l}\text { 50 lat } \\
\text { i } \\
\text { więcej }\end{array}$ & 483 & 511 & 540 & 492 & 655 & 452 & 245 & 1006 & 825 & 1110 & 533 \\
\hline Wiek & 2002 & 2003 & 2004 & 2005 & 2006 & 2007 & 2008 & 2009 & 2010 & 2011 & 2012 \\
\hline Razem & 17091 & 16444 & 14748 & 13385 & 13480 & 12663 & 10666 & 9797 & 8524 & 9199 & 8206 \\
\hline $\begin{array}{l}14-17 \\
\text { lat }\end{array}$ & 1156 & 1017 & 986 & 901 & 873 & 892 & 600 & 427 & $\ldots$ & - - & - . - \\
\hline $\begin{array}{l}18-24 \\
\text { lat }\end{array}$ & 4684 & 4218 & 3560 & 3458 & 3419 & 3080 & 2457 & 2121 &.- &.- & - . - \\
\hline $\begin{array}{l}25-29 \\
\text { lat }\end{array}$ & 3014 & 2874 & 2485 & 2343 & 2240 & 2143 & 1766 & 1769 & - . - & - . & - . - \\
\hline $\begin{array}{l}30-49 \\
\text { lat }\end{array}$ & 7315 & 7295 & 6617 & 5669 & 5903 & 5521 & 4825 & 4534 & - - - & $\ldots$ & - - - \\
\hline $\begin{array}{l}50 \text { lat } \\
\text { i } \\
\text { więcej }\end{array}$ & 922 & 1040 & 1100 & 1014 & 1045 & 1027 & 1018 & 946 & - - & - . & - . - \\
\hline
\end{tabular}

Źródło: oficjalna strona internetowa Krajowego Komitetu Statystycznego:

URL: http://www.stat.kg/stat/files/din.files/prest/506006.pdf

Liczba skazanych $\mathrm{w}$ wieku powyżej 50 lat przeciwnie - wzrosła. W roku 1991 wynosiła ona 5,4\%, a w roku 2009 - 9,6\%; trudno powiedzieć dlaczego - być może jest to związane z gwałtownym wzrostem problemów społeczno-gospodarczych w pierwszej dekadzie okresu poradzieckiego. 
Międzynarodowe normy i standardy wielką wagę przywiązują do pracy pracowników zakładów karnych. E. Coyle zauważył, że

więzienia zazwyczaj nie mogą wybierać więźniów - są one zobowiązane do przyjmowania osób skierowanych przez organy sądowe lub poprawcze. Mogą jednak wybierać personel.

Stanowisko to wyraźnie zaznaczono także we Wzorcowych regułach minimalnych postępowania $\mathrm{z}$ więźniami, przyjętych przez $\mathrm{ONZ}^{38}$, które mówią:

Administracja więzienna powinna starannie dobierać pracowników wszystkich kategorii, ponieważ dobra praca zakładów karnych zależy od rzetelności, empatii, kompetencji i cech osobistych ich pracowników ${ }^{39}$.

Po raz pierwszy termin „personel systemu wykonywania kar” wprowadzono w Kirgistanie ustawą z 12 sierpnia 2003 roku, w której określono jego prawa i obowiązki ${ }^{40}$. Personel zakładów karnych i aparatu centralnego PSW pozostaje obecnie $w$ składzie służb mundurowych i ma takie same atrybuty, jak personel placówek wojskowych. Zgodnie z zaleceniami międzynarodowych norm i standardów, zwolennicy reform dążyli do nadania pracownikom systemu penitencjarnego statusu pracowników cywilnych. Jednak psychologiczne nieprzygotowanie personelu systemu penitencjarnego do tak radykalnego kroku, strach przed utratą co najmniej części istniejących przywilejów, przysługujących im właśnie jako funkcjonariuszom służb mundurowych, zatrzymały dalszy rozwój tych inicjatyw.

W krajach rozwiniętych ogólnie przyjęty stosunek liczby osadzonych do pracowników więziennictwa wynosi trzy do jednego. W systemie więziennictwa w Kirgistanie stosunek ten wynosi sześć do jednego, co w konsekwencji negatywnie wpływa zarówno na pracownika, jak i wyniki jego pra$\mathrm{cy}^{41}$. W związku z powyższym, w systemie penitencjarnym obserwuje się dużą rotację personelu. 5-7 lat temu miał miejsce duży niedobór pracowników. Według stanu z 1 stycznia 2007 roku liczba pracowników PSW wynosiła 2476 osób, jednak wymieniono $1566^{42}$, co wynosiło 63,2\% łącznej liczby

38 Wzorcowe reguły minimalne postępowania z więźniami przyjęte przez ONZ w 1955 r., zasada 46.1 .

${ }^{39}$ M. Dżamankułow i in., Prawa czełowieka, s. 4-5.

${ }^{40}$ Ustawa Republiki Kirgiskiej o organach i zakładach systemu wykonywania kar (penitencjarnego) z 12 sierpnia 2013, nr 197, rozdział IV.

${ }^{41}$ M. Dżamankułow i in., Prawa czetowieka, s. 15, 21.

${ }^{42}$ Raport „Działalność Państwowej Służby Więziennej Ministerstwa Sprawiedliwości Republiki Kirgiskiej: wyniki 2006 roku", s. 25. 
zatrudnionych. Jeśli chodzi o proporcje płci, w systemie penitencjarnym pracowało 295 kobiet, co wynosiło 19\% łącznej liczby pracowników.

Co istotne, oczywiste są również niskie kwalifikacje pracowników systemu penitencjarnego. W trakcie szkoleń, mających na celu podnoszenie kwalifikacji, wielu pracowników wykazuje niski poziom wiedzy teoretycznej i praktycznej. Uwzględniając natomiast jeden z najważniejszych kierunków w systemie penitencjarnym, czyli działalność wychowawczą, raport końcowy PSW za 2013 rok podaje, że:

W zakładach karnych obserwowany jest niski poziom pracy wychowawczej i profilaktycznej, czego jednym z powodów jest brak odpowiedniego wykształcenia. Większość pracowników ukończyła studia zaoczne. Pracownicy społeczni i psychologowie pracujący $\mathrm{w}$ zakładach, $\mathrm{w}$ tym $\mathrm{w}$ Aparacie centralnym PSW, również nie posiadają wykształcenia kierunkowego lub pokrewnego niezbędnego do pracy w tym zakresie ${ }^{43}$.

Zasadniczo ma to negatywny wpływ na resocjalizację skazanych, na przygotowanie skazanych do zwolnienia oraz na wzrost recydywy.

Do powstania problemów kadrowych przyczynił się także wpływ subkultury kryminalnej44, która przestrzega "prawa więziennego" (niepisanych zasad) wśród więźniów.

W 2012 roku przeprowadzono monitoring miejsc pozbawienia wolności przez przedstawicieli sektora pozarządowego, a po jego zakończeniu przygotowano raport, w którym zaznaczono:

Praktyka pokazuje, że w subkulturze kryminalnej istnieje ścisły podział więźniów na kategorie grypsujących („smotriaszczije”), frajerów („mużyki”) i poszkodowanych („otwierżennyje"). Monitoring zakładów wykazał, że w najtrudniejszej sytuacji znajduje się kategoria poszkodowanych. Inni więźniowie unikają jakichkolwiek kontaktów z nimi. Zmuszani są oni do oddzielnego mieszkania i jedzenia oraz do wykonywania najbardziej brudnych prac w zakładzie ${ }^{45}$.

Literatura opisuje niemal identyczny podział kast więźniów, z niewielką tylko różnicą w liczbie i nazwach.

43 Wyniki działalności operacyjno-służbowej i finansowo-gospodarczej Państwowej Służby Więziennej przy Rządzie Republiki Kirgiskiej w roku 2013, s. 9.

44 Jako subkulturę kryminalną należy rozumieć styl życia osób połączonych $\mathrm{w}$ grupy kryminalne i przestrzegających pewnych zasad i tradycji, J. Aleksandrow, URL: http://www. litmir.net/bd/?b=128194 [dostęp: 22.02.2014].

${ }^{45}$ A. Aszyrow i in., Situacyja s prawami czełowieka w sledstwiennych izolatorach GSIN $i$ isprawitielnych uczrieżdienijach Kyrgyzskoj Riespubliki, Biszkek 2012, s. 21. 
B. Abramkin i J. Czyżow wyróżniają cztery główne kasty, przy czym kast pośrednich w każdym więzieniu może być znacznie więcej. Pierwsza, najwyższa kasta to grypsujący (błatnyje); druga, najliczniejsza to frajerzy (mużyki); trzecia, mniej lub bardziej liczna (w zależności od więzienia) to feści („kozły”); czwarta, najniższa to cwele, poszkodowani (pietuchy, otwierżennyje).

Grypsujący stanowią prawdziwą władzę w niektórych zakładach - władzę, która walczy z władzą oficjalną, czyli z administracją kolonii. Oprócz tego mają przywileje: prawo do niepracowania, prawo do przywłaszczania sobie ze „wspólnej kasy” (tzw. obszczaka) wszystkiego, co uznają za należne. Grypsujący posiadają także obowiązki: dbanie aby więzienie "grzało się", czyli otrzymywało w sposób nielegalny żywność, herbatę, tytoń, wódkę, ubrania. Zobowiązani są także do rozstrzygania sporów między innymi więźniami oraz do niedopuszczania jakichkolwiek starć między nimi, dbania, aby nikt nie został niesprawiedliwie ukarany, obrażony, czy pominięty.

Tych, którzy przestrzegają $\mathrm{w}$ kolonii lub więzieniu ustalonych zasad oraz więziennego prawa administracja nazywa "zaprzeczającymi" (otricałowka lub otricałowym). Należą do nich nie tylko grypsujący, lecz także wszyscy aktywnie przeciwstawiający się administracji.

Frajerzy o jakąkolwiek władzę w kolonii nie zabiegają, nikomu nie służą, $\mathrm{z}$ administracją nie współpracują. Wtrącać się do spraw grypsujących nie mogą. Prawa głosu na ich zebraniach (razborkach) nie mają. Wśród frajerów znajdują się jednak osoby szanowane, opinii których grypsujący słuchają, tak samo jak inni frajerzy.

Feści to więźniowie otwarcie współpracujący z administracją więzienną, którzy zgodzili się na wykonywanie jakiejkolwiek funkcji - zarządcy, kierownika klubu, bibliotekarza, komendanta kolonii.

Cwele są kastą wyrzutków, nietykalnych, wykluczonych, do której należą także pasywni homoseksualiści. Na tym samym poziomie znajduje się kasta pośrednia (czuszki, czorty), tylko z tą różnicą, że nie bywają wykorzystywani jako pasywni homoseksualiści - są tylko nietykalni ${ }^{46}$.

W 2005 roku przebywając w zakładzie nr 31 jako pracownik aparatu centralnego PSW, byłem świadkiem niedopuszczalnej dla zakładu więziennego sytuacji, kiedy skazany należący do nastawionych negatywnie grypsujących (błatnych) obrażał pracownika, a nawet stosował wobec niego przemoc fizyczną, że ten podczas sprawdzania obecności odnotował jego nieobecność w dzienniku, chociaż należało to do jego obowiązków. W okresie tym w zamkniętych zakładach karnych pracowników i więźniów dzielił mur niezgody - sytuacja była napięta do granic możliwości. W zakładach karnych

46 W. Abramkin, J. Cziżow, Kak wyżyt' w sowietskoj tiurmie, URL: http://www.prison. org/lib/sov_pris/p2_06.htm [dostęp: 01.03.2014]. 
dochodziło nawet do napaści na pracowników, a także, niestety, do zabójstw.

W raporcie analitycznym przygotowanym przez międzynarodowych ekspertów sytuację tę opisano w sposób następujący:

Na tle sparaliżowanego aparatu penitencjarnego i zużycia całej infrastruktury rozwinęła się znacznie i uzyskała dominujący wpływ subkultura kryminalna. Administracja zakładów karnych i kierownictwo systemu penitencjarnego utraciły zdolność do kontrolowania sytuacji w większości zakładów. Większość skazanych otrzymała możliwość swobodnego przemieszczania się i kontaktowania w granicach zakładu. Zaprzestali nawet przestrzegania takich elementarnych wymogów rygoru więziennego, jak apele i kontrole ${ }^{47}$.

Jesienią 2005 roku we wszystkich zakładach karnych odbyły się powszechne akcje grupowego nieposłuszeństwa, masowe zamieszki, które doprowadziły do tragicznych wydarzeńn ${ }^{48}$. W wyżej wspomnianym zakładzie podczas wizyty zostali zamordowani dyrektor Głównego Zarządu Służby Więziennej, deputowany Parlamentu i jego współpracownicy. Należy zauważyć, że morderstwa nie zostały popełnione spontanicznie, a były zorganizowane przez elity rządzące subkulturą kryminalną, która rozrosła się w systemie więziennym. Ten rażący przypadek posłużył jako lekcja dla państwa. Nie wolno zapominać o więzieniach, nawet jeśli państwo ma wiele problemów społeczno-gospodarczych. To właśnie po tym wydarzeniu państwo zaczęło zwracać większą uwagę na system penitencjarny w Kirgistanie i znormalizowało sytuację w rygorze więziennym.

Główną przyczyną powyższych problemów była trudna sytuacja finansowa i gospodarcza kraju oraz samego systemu więziennictwa.

Wysiłki podejmowane przez właściwe organy państwa nadal nie doprowadziły do należytej poprawy warunków przetrzymywania skazanych i tymczasowo aresztowanych ${ }^{49}$. Potwierdza to raport $\mathrm{z}$ monitoringu przeprowadzonego w zakładach karnych w 2012 roku przez członków Społecznej Rady Nadzorczej przy PSW. Oto jeden z fragmentów raportu:

We wszystkich koloniach karnych jednym z najbardziej palących problemów jest brak lub bardzo zły stan infrastruktury sanitarno-higienicznej, niedostateczne zaopatrzenie $\mathrm{w}$ wodę. Monitoring wykazał, że żadna $\mathrm{z}$ cel $\mathrm{w}$ aresztach śledczych oraz żaden $\mathrm{z}$ budynków w koloniach nie odpowiada w pełni minimalnym wymogom ustawodawstwa krajowego ${ }^{50}$.

47 Oficjalny dokument OBWE, s. 14.

48 Raport roczny o prawach człowieka w Republice Kirgiskiej, s. 111.

${ }^{49}$ M. Dżamankułow i in., Prawa czełowieka, s. 50.

50 A. Aszyrow i in., Situacyja s prawami czełowieka, s. 26-28. 
Według danych PSW za rok 2013, zapotrzebowanie na środki finansowe PSW w 2013 roku wynosiło 2441367500 somów (47 012661 dolarów amerykańskich), jednak z budżetu przeznaczono 836393600 somów (16106 173 dolarów amerykańskich), czyli 34,7\% zapotrzebowania.

Pomimo niedofinansowania więźniowie otrzymują pełne racje żywnościowe.

W roku 2013 wydatki na żywienie 1 osoby dzienne wynosiły:

- w zakładach karnych - 74,39 soma (1,5 dolara amerykańskiego) przy kaloryczności 3501 kcal;

- w zakładach opieki zdrowotnej - 145,05 soma (2,9 dolara amerykańskiego) przy kaloryczności 4510 kcal51.

Częściowe rozwiązanie problemów finansowych zakładów karnych ustawodawca przewidział w Kodeksie karnym wykonawczym Republiki Kirgiskiej52, który stanowi, że „skazani otrzymujący wynagrodzenie i skazani otrzymujący emerytury ponoszą koszty wyżywienia, ubrania i usług komunalnych". Jednakże, zakłady karne nie są w stanie zapewnić zatrudnienia wszystkim więźniom zdolnym do pracy.

W 2013 roku w zakładach zamkniętych zatrudniano 694 osoby ${ }^{53}$, co stanowi 12\% łącznej liczby skazanych przetrzymywanych w zakładach zamkniętych. Tak więc, większość więźniów nieposiadających zarobków nie jest $\mathrm{w}$ stanie nabyć dodatkowych produktów, wspomóc swoich rodzin, zrekompensować szkód materialnych spowodowanych złamaniem przez nich prawa. Na przykład, naprawa szkód często jest koniecznym warunkiem skorzystania przez nich z amnestii, ułaskawienia, czyli szybszego odzyskania wolności. Brak możliwości podjęcia pracy przez skazanego zawsze prowadzi do negatywnych konsekwencji społecznych i prawnych.

Obecnie powyższy problem udało się rozwiązać wyłącznie $\mathrm{w}$ kolonii żeńskiej, gdzie 90\% kobiet zatrudnionych jest (produkcja odzieży) w ramach projektu "Wsparcie reformy systemu penitencjarnego w Republice Kirgiskiej", finansowanego przez Unię Europejską i szereg innych państw. Projekt ten umożliwił także otwarcie innych przedsiębiorstw $w$ męskich zakładach zamkniętych, ale z mniejszą liczbą miejsc pracy.

Głównym celem zatrudniania więźniów jest przygotowanie ich do normalnego życia zawodowego po zwolnieniu. Można więc stwierdzić, że wskutek braku warunków do zapewnienia zatrudnienia skazanych system

51 Wyniki działalności operacyjno-służbowej i finansowo-gospodarczej Państwowej Służby Więziennej przy Rządzie Republiki Kirgiskiej, s. 10-11.

52 Kodeks karny wykonawczy Republiki Kirgiskiej z 13 grudnia 1999 roku, nr 142, art. 71.

${ }^{53}$ Wyniki działalności operacyjno-służbowej i finansowo-gospodarczej Państwowej Służby Więziennej przy Rządzie Republiki Kirgiskiej, s. 17. 
penitencjarny $\mathrm{w}$ Kirgistanie nie jest praktycznie $\mathrm{w}$ stanie przygotowywać skazanych do pracy na wolności.

Należy przy tym zauważyć, że PSW zajmuje się pomocą skazanym w zdobyciu jakiegokolwiek zawodu, który pomoże im w życiu na wolności54. Obecnie w zakładach PSW funkcjonuje 6 szkół zawodowych z filiami, w których skazani wybierają i zdobywają jeden z 20 zawodów, na które istnieje zapotrzebowanie na rynku (spawacz, elektryk, mechanik samochodowy, monter itp.). W roku szkolnym 2012/2013 w szkołach zawodowych przy zakładach PSW uczyło się 1218 uczniów, którzy otrzymali odpowiednie świadectwa55.

W Kirgistanie głównym dokumentem określającym warunki przetrzymywania osób w miejscach pozbawienia wolności jest Kodeks karny wykonawczy Republiki Kirgiskiej. Określa on procedurę oraz warunki wykonywania i odbywania kary, a także stosowanie środków resocjalizacji więźniów, status prawny skazanych, gwarantowane prawa, swobody i interesy, jak również uczestnictwo organów władzy państwowej i samorządów lokalnych, a także innych instytucji, organizacji pozarządowych i obywateli $\mathrm{w}$ resocjalizacji skazanych, procedurę zwolnienia z kary i pomocy zwolnionym $w$ adaptacji społecznej ${ }^{56}$.

Procedury i warunki przetrzymywania więźniów w zamkniętych zakładach karnych znacząco różnią się, jako że są regulowane przez właściwy dla kolonii karnych Porządek wewnętrzny zakładów karnych systemu karnego wykonawczego w Republice Kirgiskiej ${ }^{57}$.

Podstawą przyjmowania skazanych do zakładów karnych (dalej ZK) są uprawomocnione wyroki sądów lub inne dokumenty przewidziane przez prawo.

Po przybyciu skazanych do ZK sprawdzane są ich dokumenty, przeszukiwane dokładnie rzeczy, a następnie zostają poddawani, zgodnie z przepisami, kompleksowym zabiegom sanitarnym i umieszczani w kwarantannie, gdzie $\mathrm{w}$ ciągu doby przechodzą badania lekarskie oraz pozostają pod obserwacją medyczną przez następne 10 dni. Podczas kwarantanny zapoznają się z procedurą i warunkami odbywania kary, swoimi prawami i obowiązkami, jak również pouczani są o odpowiedzialności za naruszenie ustalonej

54 M. Dżamankułow i in., Prawa czełowieka, s. 111-112.

${ }^{55}$ Wyniki działalności operacyjno-służbowej i finansowo-gospodarczej Państwowej Służby Więziennej przy Rządzie Republiki Kirgiskiej, s. 9.

56 Kodeks karny wykonawczy Republiki Kirgiskiej z 13 grudnia 1999 roku, nr 142, art. 2.

57 Regulamin Państwowej Służby Więziennej przy Rządzie Republiki Kirgiskiej zatwierdzony uchwałą Rządu Republiki Kirgiskiej nr 775 z 18 grudnia 2009 roku (Regulamin PSW), pkt 1, 13, URL: http://gsin.kg/index.php?id=13 [dostęp: 12.02.2014]. 
procedury odbywania kary. Otrzymują informację, że zakład świadczy usługi w zakresie profilaktyki i leczenia narkomanii, HIV/AIDS, gruźlicy oraz innych chorób o znaczeniu społecznym, że działa biuro pomocy społecznej, w którym więźniowie mogą otrzymać pomoc prawną i psychologiczną, a także kompleksowe wsparcie w przygotowaniu do zwolnienia, jak też mają prawo do korzystania z biblioteki.

Następnie decyzją komisji ZK, kierowanej przez dyrektora zakładu, więźniowie rozdzielani są na grupy (cele), z uwzględnieniem ich cech osobowych. W skład komisji wchodzą zastępcy dyrektora ZK, przedstawiciele części medycznej i specjalnej. W koloniach poprawczych w skład komisji wchodzą ponadto pracownicy szkół ogólnokształcących i szkół zawodowych ${ }^{58}$.

Jak już wspomniano powyżej, w Kirgistanie z czterech przewidzianych przez prawo rygorów karnych (zwykły, wzmocniony, zaostrzony, nadzwyczajny) i więzienia, $\mathrm{w}$ praktyce $\mathrm{w}$ zakładach męskich działają tylko 2 rygory (wzmocniony, zaostrzony) i więzienie, w zakładzie żeńskim - tylko zwykły. W więzieniu przetrzymywani są tylko mężczyźni skazani za popełnienie szczególnie ciężkich przestępstw, w tym w recydywie, oraz wielokrotnie naruszający ustalone procedury.

Ponadto, zgodnie z Kodeksem karnym wykonawczym Republiki Kirgiskiej, każdy rygor powinien przewidywać podział na złagodzone, zwykłe i zaostrzone warunki odbywania kary pozbawienia wolności. W zależności od rygoru i warunków odbywania kary ustalana jest liczba widzeń, rozmów telefonicznych, przesyłek, paczek, które przysługują skazanym w ciągu roku. $\mathrm{W}$ więzieniu takie warunki odbywania kary nie obowiązują. W kolonii poprawczej stosowane są tylko 2 rygory - zwykły i złagodzony (patrz tab. 4).

Tabela 4

Liczba widzeń, przesyłek, paczek i rozmów telefonicznych przysługujących skazanym w zależności od rygoru i warunków odbywania kary

\begin{tabular}{|c|c|c|c|c|c|c|c|}
\hline \multirow[t]{2}{*}{ Rygory } & \multirow[t]{2}{*}{ Warunki } & $\begin{array}{l}\text { Widzenia } \\
\text { krótkie }\end{array}$ & $\begin{array}{l}\text { Widzenia } \\
\text { długie } \\
\text { (do } 3 \text { dni) }\end{array}$ & $\begin{array}{l}\text { Przesyłki } \\
\text { lub paczki }\end{array}$ & $\begin{array}{l}\text { Drobne } \\
\text { przesyłki } \\
\text { pocztowe }\end{array}$ & $\begin{array}{c}\text { Rozmowy } \\
\text { telefo- } \\
\text { niczne }\end{array}$ & $\begin{array}{c}\text { Liczba } \\
\text { zakładów }\end{array}$ \\
\hline & & \multicolumn{6}{|c|}{ liczba w ciągu roku } \\
\hline \multirow{3}{*}{ Zwykły } & złagodzone & 6 & 6 & 12 & 12 & 12 & \multirow{3}{*}{$\begin{array}{c}1 \\
\text { (dla } \\
\text { kobiet) }\end{array}$} \\
\hline & zwykłe & 6 & 5 & 10 & 6 & 10 & \\
\hline & zaostrzone & 4 & 4 & 8 & 8 & 8 & \\
\hline \multirow{3}{*}{ Wzmocniony } & złagodzone & 6 & 6 & 10 & 10 & 10 & \multirow{3}{*}{3} \\
\hline & zwykłe & 5 & 5 & 8 & 8 & 8 & \\
\hline & \begin{tabular}{|l|} 
zaostrzone \\
\end{tabular} & 4 & 2 & 6 & 6 & 6 & \\
\hline
\end{tabular}

58 Porządek wewnętrzny zakładów karnych, rozdział 3, pkt. 1-8. 


\begin{tabular}{|c|c|c|c|c|c|c|c|}
\hline \multirow[t]{2}{*}{ Rygory } & \multirow[t]{2}{*}{ Warunki } & $\begin{array}{l}\text { Widzenia } \\
\text { krótkie }\end{array}$ & $\begin{array}{l}\text { Widzenia } \\
\text { długie } \\
\text { (do } 3 \text { dni) }\end{array}$ & $\begin{array}{c}\text { Przesyłki } \\
\text { lub paczki }\end{array}$ & $\begin{array}{c}\text { Drobne } \\
\text { przesyłki } \\
\text { pocztowe }\end{array}$ & $\begin{array}{c}\text { Rozmowy } \\
\text { telefo- } \\
\text { niczne }\end{array}$ & $\begin{array}{l}\text { Liczba } \\
\text { zakładów }\end{array}$ \\
\hline & & \multicolumn{6}{|c|}{ liczba w ciągu roku } \\
\hline \multirow{3}{*}{ Zaostrzony } & złagodzone & 5 & 5 & 8 & 8 & 8 & \multirow{3}{*}{5} \\
\hline & zwykłe & 4 & 4 & 6 & 6 & 6 & \\
\hline & zaostrzone & 4 & 2 & 4 & 4 & 4 & \\
\hline \multirow{3}{*}{ Nadzwyczajny } & złagodzone & 4 & 4 & 6 & 6 & 6 & \\
\hline & zwykłe & 3 & 3 & 5 & 5 & 4 & \\
\hline & zaostrzone & 2 & 1 & 3 & 3 & 2 & \\
\hline Więzienie & & 4 & 2 & 3 & 3 & 4 & 1 \\
\hline \multirow[t]{2}{*}{$\begin{array}{l}\text { Zwykły (dla nielet- } \\
\text { nich) }\end{array}$} & preferencyjne & \begin{tabular}{|l|} 
brak \\
ograni- \\
czeń \\
\end{tabular} & 12 & \begin{tabular}{|l|} 
brak \\
ograni- \\
czeń
\end{tabular} & $\begin{array}{l}\text { brak } \\
\text { ograni- } \\
\text { czeń }\end{array}$ & 12 & \\
\hline & zwykłe & 12 & 8 & 12 & 12 & 10 & \\
\hline \multirow[t]{2}{*}{$\begin{array}{l}\text { Wzmocniony (dla } \\
\text { nieletnich) }\end{array}$} & preferencyjne & $\begin{array}{l}\text { brak } \\
\text { ograni- } \\
\text { czeń }\end{array}$ & 10 & \begin{tabular}{|l|} 
brak \\
ograni- \\
czeń
\end{tabular} & $\begin{array}{l}\text { brak } \\
\text { ograni- } \\
\text { czeń }\end{array}$ & 12 & \multirow[t]{2}{*}{1} \\
\hline & zwykłe & 8 & 6 & 10 & 10 & 8 & \\
\hline
\end{tabular}

Źródło: opracowanie własne na podstawie: Kodeks karny wykonawczy Republiki Kirgiskiej.

Należy zauważyć, że obecnie w zakładach karnych w Kirgistanie praktyka podziału na różne warunki, wskutek ograniczonych zasobów finansowych i organizacyjnych, nie ma zastosowania.

Niezależnie od rygoru, ZK cechuje specyficzny podział terytorialny. Kolonia podzielona jest na strefę przemysłową, w której znajdują się pomieszczenia produkcyjne, i strefę mieszkalną, dlatego w żargonie kryminalnym kolonia zwana jest zona (strefą). Z kolei, strefa mieszkalna podzielona jest na szereg "lokalnych stref”, w których znajdują się budynki mieszalne dla skazanych $^{59}$. Są one jedno- lub kilkupiętrowe, a więźniowie mieszkają wspólnie $\mathrm{w}$ dużych pomieszczeniach. $\mathrm{W}$ wielu koloniach powszechna jest jednak praktyka samowolnej budowy bądź przebudowy pomieszczeń, dokonywanych przez samych więźniów. W większości budynków, wobec nieprzestrzegania jakichkolwiek zasad, postawiono na stałe pełne ścianki działowe, co doprowadziło do podziału na małe pokoje lub pomieszczenia połączone przejściami i korytarzami ${ }^{6}$.

W wyniku upadku dawnej działalności przemysłowej w koloniach, wiele opuszczonych pomieszczeń przemysłowych zostało przerobionych przez skazanych na pokoje mieszkalne, toteż $\mathrm{w}$ wielu koloniach niewielka grupa więźniów mieszka także w strefach przemysłowych.

${ }^{59}$ Kolonie karne w WNP, URL http://ru.wikipedia.org/wiki/Исправительные_коло нии_в_СНГ [dostęp: 04.03.2014].

${ }^{60}$ A. Aszyrow i in., Situacyja s prawami czetowieka, s. 100. 
W każdej kolonii obowiązuje ściśle ustalony porządek dnia ${ }^{61}$, uwzględniający specyfikę pracy z konkretnymi skazanymi, porę roku i warunki lokalne.

Codziennie, rano i wieczorem, w godzinach określonych w rozkładzie dnia, sprawdzana jest obecność, a jednocześnie wygląd zewnętrzny skazanych. Kontrole przeprowadzane są w wyznaczonym miejscu podczas apelu i polegają na liczeniu oraz wywoływaniu nazwisk. Ponadto, mogą być przeprowadzane, planowane i nieplanowane, przeszukania pomieszczeń mieszkalnych skazanych oraz kontrole osobiste ${ }^{62}$.

Praca wychowawcza w kolonii przewiduje przede wszystkim stosowanie wobec skazanych zachęt ${ }^{63}$ i kar64.

Tworzenie warunków do rozwoju kulturalnego skazanych nie przebiega prawidłowo. Działalność w klubach prowadzona jest na skrajnie nieprofesjonalnym poziomie, nosi epizodyczny charakter, nie otrzymuje wsparcia materialnego. Mimo że Kodeks karny wykonawczy Republiki Kirgiskiej przewiduje możliwość tworzenia w zakładach karnych niezależnych orga-

${ }^{61}$ Przykładowy rozkład dnia skazanych: pobudka - nie później niż o 6.30; gimnastyka poranna - do 15 minut; toaleta, ścielenie łóżek - do 10 minut; przegląd poranny, kontrola poranna i wieczorna - do 40 minut; śniadanie - do 30 minut; doprowadzenie do pracy - do $40 \mathrm{mi}$ nut; praca - zgodnie z prawem pracy; przerwa obiadowa - do 30 minut; odprowadzenie z pracy, toaleta wieczorna - do 25 minut; kolacja - do 30 minut; czas wolny - do 1 godziny; zajęcia wychowawcze - do 1 godziny; zajęcia kulturalne, zajęcia w szkole ogólnokształcącej lub zawodowej - zgodnie z osobnym regulaminem; przygotowanie do snu - do 10 minut; sen (ciągły) - 8 godzin; udanie się na spoczynek - nie później niż o godz. 22.30. Porządek wewnętrzny zakładów karnych, rozdział 4.

62 Porządek wewnętrzny zakładów karnych, rozdział 10, pkt 1-2.

63 Za dobre zachowanie, rzetelny stosunek do pracy, kształcenie się, aktywny udział w pracy, amatorskich organizacjach i działaniach wychowawczych w stosunku do osądzonych mogą być stosowane następne środki motywujące: 1) wyróżnienie; 2) wręczenie dyplomu i dyplomu honorowego; 3) wręczenie prezentu; 4) przyznanie premii; 5) pozwolenie na otrzymanie dodatkowej przesyłki lub paczki; 6) pozwolenie na dodatkową rozmowę telefoniczną; 7) przyznanie dodatkowego krótkiego lub długiego widzenia; 8) pozwolenie na dodatkowe wydanie kwoty nie przekraczającej jednej czwartej ustalonego przez prawo minimalnego wynagrodzenia na zakup produktów żywnościowych i przedmiotów pierwszej potrzeby; przedterminowe odwołanie nałożonej wcześniej kary. Kodeks karny wykonawczy Republiki Kirgiskiej z 13 grudnia 1999 roku, nr 142, s. 85.

${ }^{64}$ Za naruszenie ustalonego porządku odbywania kary w stosunku do osądzonych mogą być stosowane następujące kary: 1) nagana; 2) kara dyscyplinarna w wysokości dwóch minimalnych wynagrodzen; 3) umieszczenie osadzonych odbywających karę w koloniach karnych lub więzieniach, w izolatce na okres do piętnastu dni; 4) przeniesienie skazanych mężczyzn, wielokrotnie naruszających ustalony porządek odbywania kary, odbywających karę w zakładach karnych o zwykłym, wzmocnionym i zaostrzonym rygorze, do pomieszczeń typu cela, a w koloniach o nadzwyczajnym rygorze - do cel pojedynczych na okres do sześciu miesięcy; 5) przeniesienie skazanych kobiet, wielokrotnie naruszających ustalony porządek odbywania kary, do pomieszczenia typu cela na okres do trzech miesięcy. Kodeks karny wykonawczy Republiki Kirgiskiej z 13 grudnia 1999 roku, nr 142, s. 87. 
nizacji skazanych, niestety do tej pory nie ustalono procedury ich powoływania i działalności65. Przy czym, skazanym praktycznie pozwolono we wszystkich zakładach karnych na posiadanie telewizorów i radioodbiorników, co w pewnym stopniu organizuje czas wolny i jest sposobem na pozyskiwanie informacji.

W ZK popularne są także imprezy sportowe, szczególnie mecze piłki nożnej i siatkówki, często odbywające się między drużynami pracowników i skazanych, co z kolei pozytywnie wpływa na ich wspólne relacje.

Aktualnym problemem podczas zwalniania skazanych jest brak posiadania przez nich dowodów osobistych, jako że trafiają oni do miejsc pozbawienia wolności bez dokumentów tożsamości, które często są gubione w trakcie dochodzenia, rozprawy sądowej itp.

Dzięki finansowemu wsparciu organizacji międzynarodowych, uruchomiono biura społeczne, które działają w 13 zakładach systemu penitencjarnego. Prowadzą one prace $\mathrm{w}$ zakresie wydawania legitymacji opieki społecznej $\mathrm{z}$ numerem identyfikacyjnym (dalej indywidualny numer identyfikacyjny - INI) i dowodów osobistych ${ }^{66}$.

W 2013 roku dowody osobiste otrzymało w ten sposób 168 skazanych, natomiast INI - 1261, podczas gdy w okresie tym zwolniono 1962 osoby ${ }^{67}$. Tak więc, odsetek osób zwolnionych bez dowodu osobistego nadal jest duży. Brak państwowego mechanizmu resocjalizacji skazanych po zwolnieniu utrudnia pracę wyżej wymienionych biur.

Niestety, w takiej sytuacji, w większości przypadków, osoba zwolniona z więzienia nie ma możliwości normalnego powrotu do społeczeństwa i udanej adaptacji.

Współczesny system penitencjarny w Kirgistanie w zaprezentowanym tu kształcie przypomina młody organizm będący lustrzanym odbiciem społeczeństwa, w którym funkcjonuje. Stoi przed nim ogromna liczba nierozwiązanych problemów, ale także szereg możliwości wyboru właściwej drogi dalszego rozwoju, co stanowi też pewien atut.

${ }^{65}$ M. Dżamankułow i in., Prawa czełowieka, s. 125-126.

${ }^{66}$ S. Basztowienko, E. Ajdarow, Rukowodstwo po socyalnoj rabotie s pożytymi licami, otbywajuszczimi nakazanije w uczrieżdienijach pienitiencyarnoj sistiemy Kyrgyzskoj Riespubliki, Biszkek 2012, s. 10.

67 Wyniki działalności operacyjno-służbowej i finansowo-gospodarczej Państwowej Służby Więziennej przy Rządzie Republiki Kirgiskiej, s. 9-10. 
Z analizy danych statystycznych, wykorzystanej literatury, raportów PSW wyłania się obraz otwartego systemu penitencjarnego, który aktywnie wchodzi w interakcje ze światem zewnętrznym. Tak więc, kierunek rozwoju systemu penitencjarnego w Kirgistanie staje się oczywisty.

Badanie systemu więziennictwa w Kirgistanie wykazało, że istnieje wiele różnych problemów. Jednak każdy problem można rozwiązać. Najważniejsze, aby wykazać się wytrwałością i chęcią, od których zależy los rozpatrywanego systemu: czy będzie on represyjny i skostniały czy humanitarny i postępowy 68 .

Historia światowa i praktyka z zakresu polityki karnej wykonawczej pokazują, że stosowanie represyjnych kar przy wydawaniu wyroków nie prowadzi do spadku przestępczości, a wręcz przeciwnie - do jej wzrostu, a tym samym do regresu społeczeństwa. Nasuwa się zatem wniosek, że im więcej osób jest pozbawionych wolności, tym mniejszą rolę odgrywają jakiekolwiek metody resocjalizacji i praktyki mające na celu poprawę odbywającego karę przestępcy.

Trafne są w tym kontekście słowa kirgiskiego prawnika A. Szagiwalijewa: „resocjalizacją przestępcy lepiej zajmować się nie w warunkach izolacji od społeczeństwa, a w naturalnym środowisku człowieka".

Co oczywiste, Kirgistan stoi na początku drogi do humanitarnej i progresywnej polityki karnej. Jednakże, droga ta nie będzie łatwa, ponieważ nie zostały rozwiązane problemy społeczno-gospodarcze, jakie wystąpiły po uzyskaniu niepodległości, jak również nadal istnieją pozostałości radzieckiego systemu represyjnego.

Podsumowując, chciałbym zwrócić uwagę, że głównym celem tej pracy było przedstawienie obecnego stanu systemu więziennictwa w Kirgistanie oraz drogi, jaką odbył on od systemu zamkniętego i represyjnego do otwartego i humanitarnego $\mathrm{w}$ okresie niepodległości, a także problemów mogących wystąpić na tej trudnej drodze. Kirgistan może służyć za przykład, a jaki to przykład - pozostawiam ocenie samego czytelnika.

\section{BIBLIOGRAFIA}

„For.kg”, adres internetowy: http://www.for.kg/kyrgyzstan-ru.html.

International Centre for Prison Studies, adres internetowy: http://www.prison studies.org/country/.

Kodeks karny wykonawczy Republiki Kirgiskiej z 13 grudnia 1999 roku, nr 142.

${ }^{68}$ A. Szagiwalijew i in., Gumanizacyja ugołownogo zakonodatielstwa Kyrgyzskoj Riespubliki: problemy tieorii i praktiki, Biszkek 2009, s. 271. 
Konstytucja Republiki Kirgiskiej wprowadzona w życie ustawą Republiki Kirgiskiej z 27 czerwca 2010 roku.

Oficjalna strona internetowa Prezydenta Kirgistanu: http://www.president.kg/ru/ kyrgyzstan/.

Oficjalna strona internetowa Krajowego Komitetu Statystycznego Kirgistanu: http://stat.kg/images/stories/docs/Yearbook/Demo/3.\%20chislennost\&20i\%20plo t.pdf.

Porządek wewnętrzny zakładów karnych w Republice Kirgiskiej zatwierdzony uchwałą Rządu Republiki Kirgiskiej nr 604 z 23 września 2011.

Regulamin Państwowej Służby Więziennej przy Rządzie Republiki Kirgiskiej zatwierdzony uchwałą Rządu Republiki Kirgiskiej nr 775 z 18 grudnia 2009 roku.

Recidivism, adres internetowy: http://en.wikipedia.org/wiki/Recidivism.

Religia w Kirgistanie, adres internetowy: http://www.advantour.com/rus/kyrgyzstan/ religion.html.

Wzorcowe reguły minimalne postępowania z więźniami przyjęte w Genewie w 1955 r. przez Pierwszy Kongres Narodów Zjednoczonych w Sprawie Zapobiegania Przestępczości i Postępowania ze Sprawcami Przestępstw i zaaprobowane przez Radę Gospodarczą i Społeczną w rezolucji 663C (XXIV) z dnia 31 lipca 1957 r. oraz 2076 (LXII) z dnia 13 maja 1977 r.

Abramkin W., Cziżow J., Kak wyżyt' w sowietskoj tiurmie, adres internetowy: http://www.prison.org/lib/sov_pris/p2_06.htm.

Agiejewa J., Żenskaja priestupnost': sowriemiennoje położenije i pricziny, Sledowatel, 2001, 6, s. 39-40, adres internetowy: http://www.gadost.hut.ru/clog9.html.

Aszyrow A., Biegalijew D., Wocława J., Ismaiłowa T., Krapiwina J., Kurmanowa N., Esienomanowa E., Situacyja s prawami czełowieka w sledstwiennych izolatorach GSIN $i$ isprawitielnych uczrieżdienijach Kyrgyzskoj Riespubliki, Biszkek 2012.

Basztowienko S., Ajdarow E., Rukowodstwo po socyalnoj rabotie s pożytymi licami, otbywajuszczimi nakazanije w uczrieżdienijach pienitiencyarnoj sistiemy Kyrgyzskoj Riespubliki, Biszkek 2012.

Bytko J., Uczenije o riecydiwie priestuplenij w rossijskom ugolownom prawie: Istorija i sowriemiennost', Diessiertacyja, adres internetowy: http://www.dissercat.com/ content/uchenie-o-retsidive-prestuplenii-v-rossiiskom-ugolovnom-prave-istoriya-isovremennost.

Dołgowa A.I. (red.), Kriminologija: Uczebnik dla wuzow, Moskwa 2001, adres internetowy: http://ru.wikipedia.org/wiki/Licznost'_priestupnika\#cite_note-18.

Dril D., Małoletnije priestupniki. Etiud po woprosu o czełowieczeskoj priestupnosti, jejo faktorach $i$ sriedstwach borby s niej, Moskwa 1884, adres internetowy: http://yurpsy.com/ files/biblio/dril/05.htm

Działalność Państwowej Służby Więziennej Ministerstwa Sprawiedliwości Republiki Kirgiskiej: wyniki 2006 roku.

Dżamankułow M., Abdukuł uułu M., Saparbajew B., Szagiwalijew A., Omurkanowa Cz., Isakunowa T., Kasymbiekow A. (red.), Prawa czetowieka w processie rieformirowanija pienitiencyarnoj sistiemy w Kyrgyzskoj Riespublikie, Biszkek 2007.

Evaluation of the state of the penitentiary system of the Kyrgyz Republic, Bishkek 2006.

GUŁAG, adres internetowy: http://ru.wikipedia.org/wiki/\%D0\%93\%D0\%A3\% $\mathrm{D} 0 \% 9 \mathrm{~B} \% \mathrm{D} 0 \% \mathrm{~B} 0 \% \mathrm{D} 0 \% \mathrm{~B} 3$.

Jakowlew A., Indiwidualnaja profilaktika priestupnogo powiedienija, Gorki 1997. 
Kolonie karne w WNP, adres internetowy: http://ru.wikipedia.org/wiki/Isprawitie lnyje_kolonii_w_SNG.

Ostrow Bastoj: norwieżskaja tiurma dla osobo opasnych priestupnikow, adres internetowy: http:/ /ttolk.ru/?p=4220.

Prawa osób starszych w miejscach pozbawienia wolności w Republice Kirgiskiej (raport z pierwszego monitoringu), Biszkek 2011.

Raport roczny o prawach człowieka w Republice Kirgiskiej w roku 2006, Biszkek 2007. Raport Wydziału Wykonywania Orzeczeń Sądowych i Ewidencji PSW z 01.07.2012 r.

Szagiwalijew A., Sadykowa L., Dżamankułow M., Apaitowa K., Abdukul uulu M., Zubow S., Gumanizacyja ugołownogo zakonodatielstwa Kyrgyzskoj Riespubliki: problemy tieorii i praktiki, Biszkek 2009.

Ustawa Republiki Kirgiskiej o organach i zakładach systemu wykonywania kar (penitencjarnego) z 12 sierpnia 2013 r., nr 197.

Ustawa Republiki Kirgiskiej o wprowadzeniu zmian i uzupełnień do Kodeksu karnego Republiki Kirgiskiej, Kodeksu postępowania karnego Republiki Kirgiskiej, Kodeksu postępowania administracyjnego Republiki Kirgiskiej, Kodeksu karnego wykonawczego Republiki Kirgiskiej, do ustaw Republiki Kirgiskiej o Sądzie Najwyższym Republiki Kirgiskiej i sądach lokalnych, o prokuraturze Republiki Kirgiskiej, o trybie i warunkach przetrzymywania $\mathrm{w}$ areszcie osób zatrzymanych $\mathrm{w}$ związku z podejrzeniem popełnienia przestępstwa i oskarżonych o popełnienie przestępstwa, o ogólnych zasadach amnestii i ułaskawienia, o wprowadzeniu w życie Kodeksu karnego wykonawczego Republiki Kirgiskiej oraz o wprowadzeniu w życie Kodeksu karnego Republiki Kirgiskiej (ustawa o humanizacji) opublikowana w gazecie „Erkin-TOO” 3 lipca 2007 r.

Wyniki działalności operacyjno-służbowej i finansowo-gospodarczej Państwowej Służby Więziennej przy Rządzie Republiki Kirgiskiej w roku 2013. 